\title{
Genetic variation between and within populations of a perennial grass: Arrhenatherum elatius
}

\author{
Alexis Ducousso, \\ Daniel Petit, \\ Myrian Valero and \\ Philippe Vernet
}

Laboratoire de Génétique et Evolution des

Populations Végétales, U.R.A. CNRS 1185, Université

de Lille 1, 59655 Villeneuve d'Ascq Cedex, France.

Three pairs of adjacent populations of Arrhenatherum elatius were studied both for their genetic diversity and for their genotypic structure. Each pair consisted of one population on a normal soil type and the other on spoil from mining.

Using morphological characters as well as allozyme markers, the genetic diversity in populations on toxic soils (mining spoil) was found to be higher than in populations in normal pasture. This suggests that the tolerant populations have been built up from a large number of tolerant genotypes emanating from normal pasture populations in which tolerance genes are not uncommon. The higher genetic diversity of the tolerant population has then been maintained by the spatial heterogeneity of toxic habitats, or less intense selective forces of biotic origin (e.g. intraspecific competition) or by a more open breeding system.

Variations in allozymes gave interesting clues. No clear cut differences in the genetic structure between pairs of populations were found, but there was a higher heterozygote deficit in denser populations.

This might arise from inbreeding because of a more limited gene flow in dense populations. The higher genetic diversity of sparse populations on toxic soil might partly result from the effectively greater gene flow into these populations in which individuals must trap pollen from longer distances than do individuals in dense populations.

\section{INTRODUCTION}

Studies on genetic variation between pairs of populations consisting of one population on normal soil and the other on adjacent mine spoil are still rare. Although some comparative studies are available concerning genetic diversity (Lefebvre and Kakes, 1978, Wu et al., 1975, Verleij et al., 1985) almost nothing is known concerning genotypic structure.

From a theoretical point of view, it is conventionally admitted that selection, even when strong, does not reduce genetic diversity of the genome, except, of course, for the loci involved in the selection process. Nevertheless, if strong selection acts on a mutation which is very rare in nature and non-recurrent, it will introduce a very strong bottleneck. The genetic variation of the genome will therefore be strongly reduced. The occurrence of individuals tolerant to heavy metals is quite frequent in some plant species: in Agrostis tenuis and Dactylis glomerata the frequency of full copper tolerance was found to be 0.8 per cent (Gartside and McNeilly, 1974). Indeed, using morphological characters as well as enzyme markers, the genetic diversity of populations of Agrostis stolonifera on toxic soil was found to be at least as great as in the normal habitat and even greater (Wu et al., 1975). This result can be explained (i) by a high level of tolerant plants in natural populations (the mutation is not rare and probably recurrent); or (ii) by successive colonizing events in the tolerant population so that the bottleneck induced by selection has not occurred.

To explain the lower level of genetic diversity occurring in the normal habitat, Wu et al. (1975) pose the question of the different population density on normal and toxic soil. Is the reduced genetic variability due to stronger competition between clones in normal soil than in the toxic habitat? With regard to genotypic structure two mechanisms which reduce gene flow have been described: phenological drift (McNeilly and Antonovics, 1968) and increase in self-fertilisation (Antonovics, 1968, Lefebvre 1970). Therefore, one would expect that a population from toxic zones, which has departed from panmixia, would present a more or less important heterozygote deficit compared to an adjacent normal population. Moreover, population density must also be considered in assessing genotypic structure: vicinity 
favours gene flow between individuals of an allogamous species.

This paper has two aims:

(1) to compare the genetic diversity of a perennial grass (A. elatius) found in toxic and normal habitats. The genetic diversity will be studied in respect to morphological, phenological and biochemical characters.

(2) to study, using allozyme markers, variation in genotypic structure between and within populations, using three pairs of closely adjacent populations of this grass.

\section{MATERIALS AND METHODS}

Arrhenatherum elatius is a perennial autotetraploid grass $(4 x=28)$. This wind-pollinated and allogamous species is able to colonize a great range of habitats in northern France (fallow land, meadow, dunes, colliery spoil heaps, areas polluted with heavy metals). Three study sites located in the mining and coal areas of northern France were chosen for their tolerant colonizing populations of $A$. elatius on spoils (T1, T2, T3) and their adjacent normal ones on loamy soils (N1, N2, N3), (table 1). Site 1, located in Auby (Pas-de-Calais) on zinc ore waste (calaminary waste) near a smelting plant is characterised by high levels of heavy metals (lead, zinc, cadmium) in the soil. Sites 2 and 3 are situated respectively in Henin-Beaumont
(Pas-de-Calais) and in Auchy-les-Mines (Pas-deCalais) on colliery spoil heaps characterised by an abnormal magnesium/calcium ratio $(\mathrm{Mg} / \mathrm{Ca}>$ $0 \cdot 88)$.

At these sites, transects from toxic $(T)$ to normal $(\mathrm{N})$ habitat and quadrats in normal or toxic habitats were made to compare tolerant and normal populations.

Phenology was studied in all plants of quadrats chosen to contain at least 100 plants. Two observations were made, one during June and the other during July, except for site 1 where phenology was followed each week to estimate length of flowering time. Sixteen recognised phenological stages (Ducousso, 1985) from tillering to seed fall enabled us to classify each plant into one stage.

Along transects, one plant every metre (when possible), was partly sampled and cultivated in an experimental garden for morphological studies (height of panicles, node colour and hairiness).

Nodes are very variable in colour and hairiness (entirely green or red, with red ring or not, without hairs or with hairs above, under or everywhere on the node), but all nodes of one plant are similar and do not vary with the environment. Each node type has been described.

Cultivated plants taken from the transects were also used for enzymatic studies. Different enzyme systems were examined using vertical polyacrylamide gel electrophoresis (Orstein and Davis, 1964, modified by Gasquez and Compoint, 1976).

Table 1 The three pairs of adjacent stations studied and their main characteristics

\begin{tabular}{|c|c|c|c|c|c|c|c|c|c|}
\hline \multirow[b]{2}{*}{ Sites } & \multirow[b]{2}{*}{ Stations } & \multicolumn{2}{|c|}{$\begin{array}{l}\text { Heavy metal } \\
\text { content (ppm) }\end{array}$} & \multirow[b]{2}{*}{$\begin{array}{l}\mathrm{Mg} / \mathrm{Ca} \\
\text { ratio }\end{array}$} & \multirow{2}{*}{$\begin{array}{l}\text { Density of } \\
\text { Arrhenatherum } \\
\text { populations } \\
\text { (panicles } / \mathrm{m}^{2} \text { ) }\end{array}$} & \multirow{2}{*}{$\begin{array}{l}\text { Number of } \\
\text { species } \\
\text { in the } \\
\text { communities }\end{array}$} & \multirow[b]{2}{*}{ Dominant species } & \multicolumn{2}{|c|}{ plants studied } \\
\hline & & $\mathrm{Zn}$ & $\mathrm{Pb}$ & & & & & $\begin{array}{l}\text { Along } \\
\text { transect }\end{array}$ & $\begin{array}{l}\text { In } \\
\text { quadrat }\end{array}$ \\
\hline 1 & $\begin{array}{l}\text { N1 (normal soil) } \\
\text { T1 (Heavy metal) } \\
\text { (spoils } \mathrm{Pb}, \mathrm{Zn} \text { ) }\end{array}$ & 1919 & 463 & $0 \cdot 14$ & 61 & 22 & $\begin{array}{l}\text { Arrhenatherum } \\
\text { elatius } \\
\text { Armeria maritima } \\
\text { Arrhenatherum } \\
\text { elatius }\end{array}$ & 52 & 109 \\
\hline 2 & $\begin{array}{l}\text { N2 (normal soil) } \\
\text { T2 (colliery spoils) }\end{array}$ & $4 \cdot 8$ & $\begin{array}{l}4 \cdot 6 \\
5 \cdot 2\end{array}$ & $\begin{array}{l}0.17 \\
0.88\end{array}$ & $\begin{array}{r}352 \\
69\end{array}$ & $\begin{array}{l}21 \\
11\end{array}$ & $\begin{array}{l}\text { Arrhenatherum } \\
\text { elatius } \\
\text { Rumex scutatus } \\
\text { Arrhenatherum } \\
\text { elatius }\end{array}$ & 35 & 193 \\
\hline 3 & $\begin{array}{l}\text { N3 (normal soil) } \\
\text { T3 (colliery spoils) }\end{array}$ & - & $\begin{array}{l}1 \\
0 \cdot 7\end{array}$ & $\begin{array}{l}0 \cdot 089 \\
2 \cdot 1\end{array}$ & $\begin{array}{l}85 \\
1 \cdot 6\end{array}$ & $\begin{array}{l}22 \\
13\end{array}$ & $\begin{array}{l}\text { Dactylis glomerata } \\
\text { Pastinaca sativa } \\
\text { Arrhenatherum } \\
\text { elatius }\end{array}$ & $\begin{array}{r}35 \\
113\end{array}$ & $\begin{array}{l}211 \\
555\end{array}$ \\
\hline
\end{tabular}

$\mathrm{N}=$ normal habitats; $\mathrm{T}=$ toxic habitats. 
The genetic basis of the gel-banding patterns was determined by comparison of isozyme phenotypes from selfing or crossing progenies with those of their parents (Loutfi, 1987).

Allozyme polymorphism is reported for three loci: glutamate oxaloacetate transaminase-1 $(G O T-1)$ with five alleles: $1 \cdot 08,1 \cdot 04,1 \cdot 00,0.92$, 0.84 , coding for a dimeric enzyme; glutamate oxaloacetate transaminase-2 (GOT-2) with seven alleles: $1.05,1.00 ; 0.94,0.88,0.82,0.80,0.70$, coding for a dimeric enzyme; alcohol dehydrogenase $(A D H)$ with three alleles: $1 \cdot 12,1 \cdot 00,0 \cdot 88$, coding for a monomeric enzyme.

For the tetrazolium oxidase system (TO), where the genetic basis of the banding pattern is still unknown, only the isozyme phenotypes have been used.

To estimate diversity in the different populations, the Shannon and Weaver diversity index (Shannon and Weaver, 1963) was applied to the various characters, whether phenotypes, genotypes or allelic frequencies. This index $\left(I_{s}\right)$ is given by the formula:

$$
\mathrm{I}_{\mathrm{s}}=\sum_{i=1}^{n}-x_{i} \log _{2} x_{i}
$$

where $x_{i}$ is the frequency of the $i$ th class of the characters studied in the population and $n$ the number of classes. To test if the environment (normal or toxic) has an effect on the level of diversity two methods were used. (1) For each character studied and at each site $(1,2,3)$, the Shannon index calculated for normal soil was compared to that obtained for toxic soil using Hutcheson's test (1970); (2) a three-way factorial analysis of variance was made to test the respective effect of toxicity (normal/toxic), sites $(1,2,3)$, and character studied (phenology, nodes, height, $A D H, G O T$ $1, G O T-2)$ on the Shannon index. The model used is a mixed model (Sokal and Rohlf, 1981), the sites and characters being random effects and the toxicity being a fixed effect.

Genotypic structure was studied in cultivated plants taken from the different transects and for a complementary quadrat made on a zinc ore grassland where the population shows high and low density levels. It was therefore possible to separate density effects from toxic effects.

Wright's inbreeding coefficient, $F$, modified by Lumaret (1981) for tetraploids was used to estimate deviations from the Hardy-Weinberg expectation:

$$
F=1-\frac{H_{\mathrm{o}}}{H_{\mathrm{e}}}
$$

where $H_{\mathrm{e}}$ and $H_{\mathrm{o}}$ are respectively the expected and observed proportions of heterozygotes.

In the tetraploid $A$. elatius $H_{\mathrm{e}}$ was estimated by the proportion of heterozygote gametes:

$$
H_{\mathrm{e}}=1-\sum_{i=1}^{m} s_{i}^{2}
$$

where $s_{\mathrm{i}}$ is the allelic frequency of the $i$ th allele at the locus presenting a total of $m$ alleles.

The probability of heterozygote gametes from the heterozygotes iiij, iijj, iijk, ijkl is respectively $1 / 2,2 / 3,5 / 6$ and 1 . Therefore $H_{\mathrm{o}}$ is given by:

$$
H_{\mathrm{o}}=\frac{1 / 2 x(\mathrm{iiij})+2 / 3 y(\mathrm{iijj})+5 / 6 z(\mathrm{iijk})+w(\mathrm{ijkl})}{N}
$$

where $N$ is the number of individuals analysed and $x, y, z$, and $w$ are the number of individuals in different classes of heterozygotes.

This estimate of $F$ includes effects due to inbreeding and population sub-structure. Although it was not possible to separate these effects in this study, comparison of $F$ values reflects variation in genotypic structure between population. Positive values of $F$ can be interpreted as the average inbreeding coefficient of population.

Soil heterogeneity which can be a factor of diversity has been estimated at site 1 through its heavy metal content. Soil collected from the rhizosphere of each sampled plant were dried at room temperature and sifted $(2 \mathrm{~mm})$. Heavy metals were extracted by boiling $1 \mathrm{~g}$ of soil with $25 \mathrm{ml}$ of concentrated nitric acid for 1 hour and $\mathrm{Zn}$ and $\mathrm{Pb}$ were measured using an atomic absorption spectrophotometer.

\section{RESULTS}

\section{Zinc and lead content in soils}

Zinc and lead content is often high and at a toxic level on the zinc ore waste land. However, contents comparable to those of the normal habitat are also found (fig. 1).

So even in a toxic area, an individual can meet normal soil conditions.

\section{Diversity analysis}

Phenological diversity estimated by the timing and duration of the flowering period is clearly higher in the toxic habitat (fig. 2). Ten different phenotypes are observed compared to only one on normal soil. The other estimate of phenological diversity - sorting individuals into phenological 

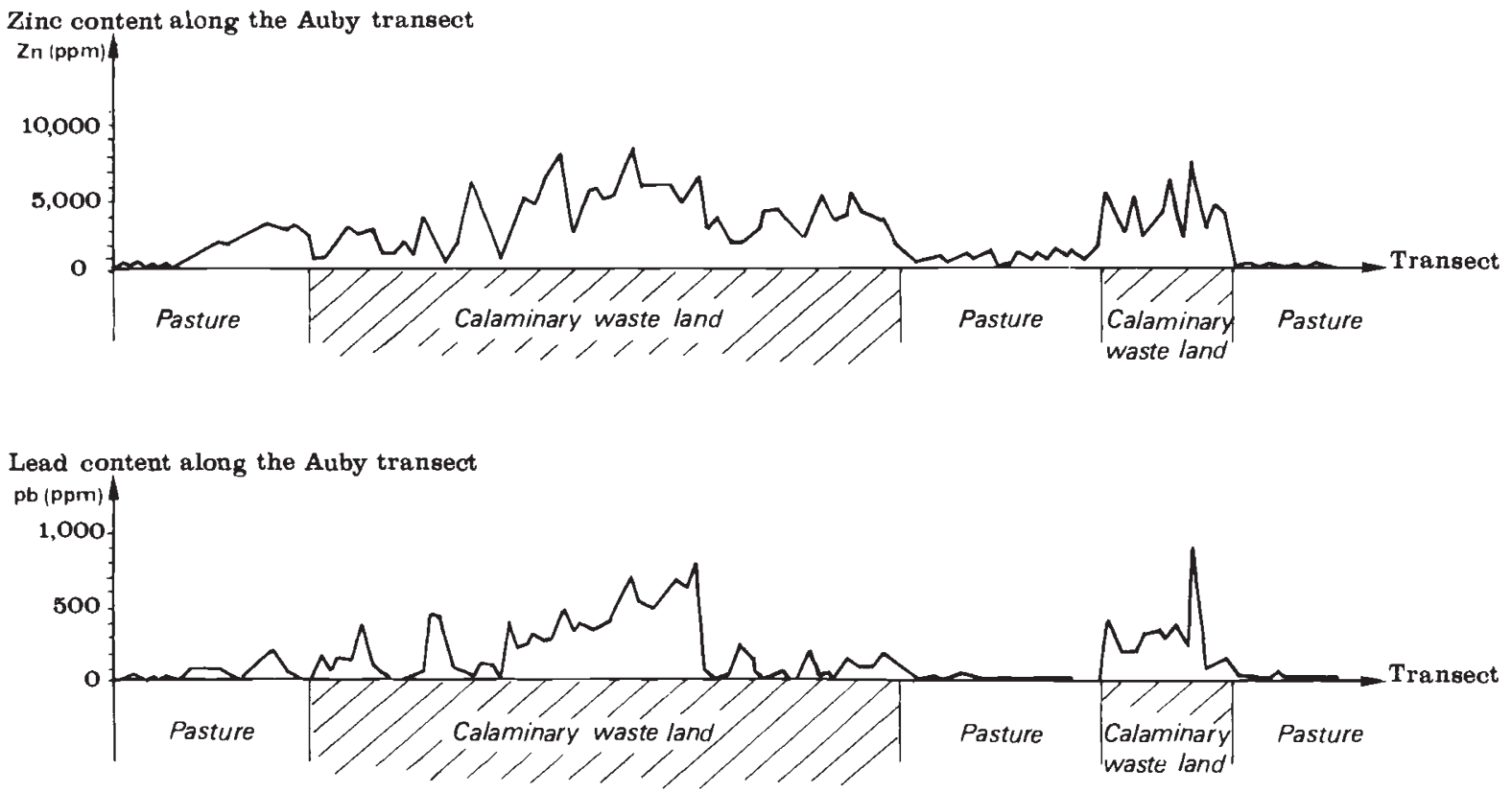

$\mapsto 1$ mètre

Figure 1 Variability in total lead and zinc content along the Auby transect. Samples were taken each metre in the soil within groups of Arrhenatherum elatius (Sites T1 and N1).

classes (Ducousso, 1985)-leads to the same result: the number of classes is significantly higher (Shannon index) on mine soil (table 2).

Red-coloured nodes appear more frequently on toxic habitats whereas they are more often green on normal sites. Small differences in hairiness are also noted between populations. A significantly higher diversity on toxic land is again underlined by the Shannon index (table 2 ).

Panicle height is greater in normal populations $(134-142 \mathrm{~cm})$ than in toxic habitats $(50-92 \mathrm{~cm})$. Here again the diversity is significantly higher in the toxic areas (table 2).

Only three or four phenotypes are found in the TO system for the pasture population whereas between seven and eleven are found in the mine population. (Plants were not scored for TO at site 3.) The Shannon index confirms the significantly higher diversity in the toxic habitat for this character (table 2).

At the $A D H$ locus (table 3 ) one allele (1.00) has a frequency greater than 0.80 in the pasture populations whereas in the spoil populations its frequency is less than $0 \cdot 60$. The alleles $1 \cdot 12$ and 0.88 are much more frequent in the toxic habitat. Allelic diversity is significantly higher in toxic habitats (Shannon index).
At the GOT-2 locus (table 4) a higher allelic diversity is found in the spoil populations which is due to 2-4 infrequent alleles which are absent or extremely rare in pasture populations. However, at site 1 , the Shannon index is not significantly different between normal and toxic habitats.

At the GOT-1 locus, (table 4) the number of alleles is higher in the normal habitat than in the toxic one. In contrast to the results obtained for the other characters studied previously, an increasing diversity at this locus is observed on normal soils.

None of these three loci seems to be undergoing selection in the sites studied (Ducousso, 1985).

The results of the factorial analysis of variance (table 5) show a strong effect of characters on variation in Shannon indices. In particular, these indices are higher for phenotypic traits (table 2) than for enzyme loci (tables 3 and 4). The effect of the environment (normal or toxic) on variation in diversity is just significant $(P=0 \cdot 053$, table 5$)$. Nevertheless, a strong interaction occurs between level of toxicity and the kind of character studied: Shannon indices do not respond in the same way to toxic environments with the trait studied. At the locus GOT-1 (table 4) diversity increases in normal habitats whereas in the same conditions it 


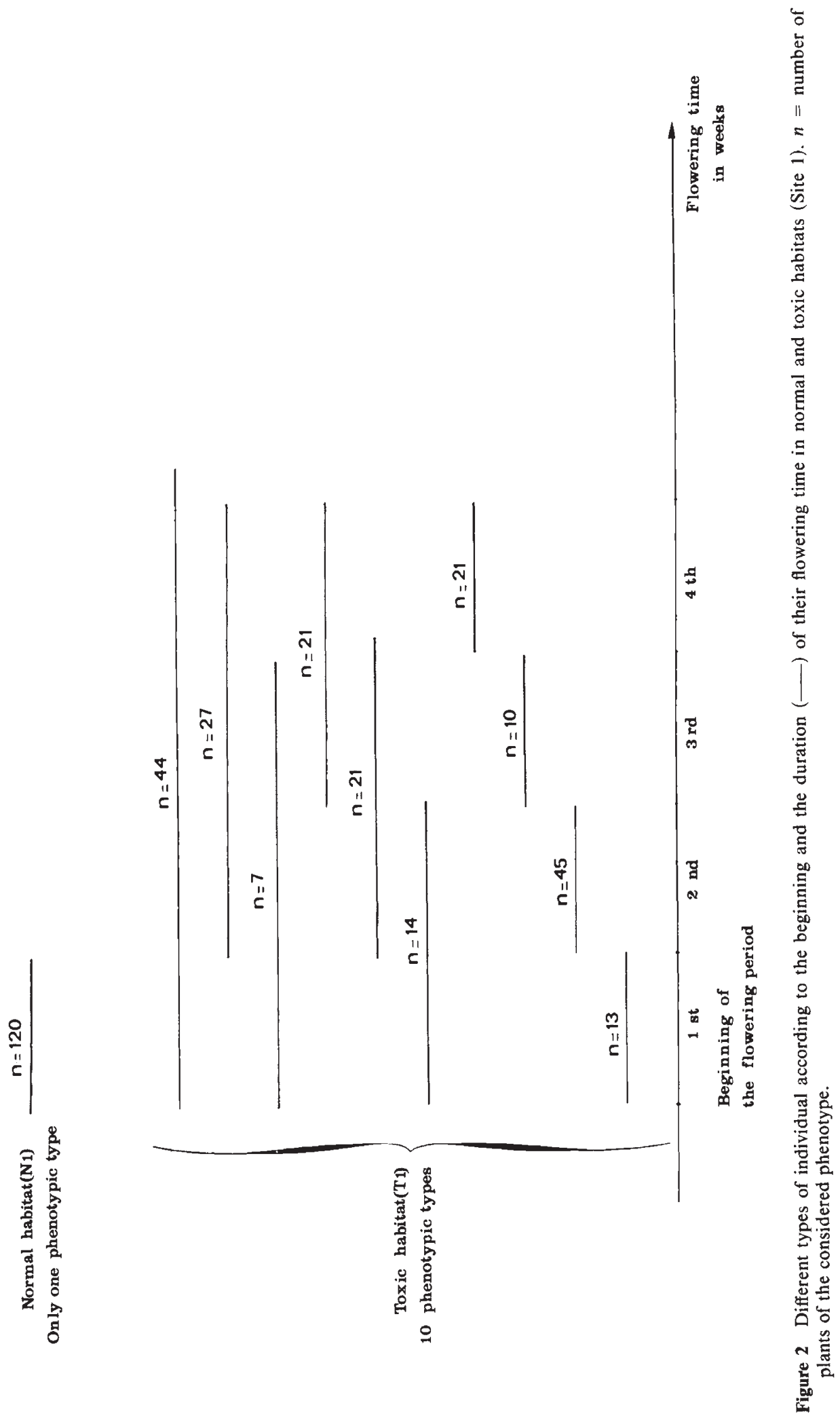


Table 2 Number of classes or phenotypes and diversity indexes for phenology, node characters of floral spike, plant height, tetrazolium oxidase (TO) system in normal soil (N) and mine spoil (T) populations of Arrhenatherum elatius

\begin{tabular}{|c|c|c|c|c|c|c|}
\hline Type of populations & N1 & $\mathrm{T} 1$ & $\mathrm{~N} 2$ & $\mathrm{~T} 2$ & N3 & $\mathrm{T} 3$ \\
\hline \multicolumn{7}{|l|}{ Phenology } \\
\hline Number of individuals & 109 & 355 & 193 & 812 & 211 & 555 \\
\hline Number of classes & 6 & 10 & 7 & 10 & 4 & 10 \\
\hline Shannon's index & $1 \cdot 587$ & $2 \cdot 104$ & \multirow{2}{*}{\multicolumn{2}{|c|}{$1 \cdot 832 * * *$}} & \multirow{2}{*}{\multicolumn{2}{|c|}{$1 \cdot 103$}} \\
\hline$P^{\$}$ & \multicolumn{2}{|c|}{ **** } & & & & \\
\hline Number of sampled individuals & 109 & 355 & 193 & 812 & 211 & 555 \\
\hline Number of observed phenotypes & 16 & 54 & 18 & 36 & 15 & 47 \\
\hline Shannon's index & $2 \cdot 779$ & $4 \cdot 053$ & \multirow{2}{*}{\multicolumn{2}{|c|}{$\begin{array}{r}2 \cdot 4 / 0 \\
* * *\end{array}$}} & \multirow{2}{*}{\multicolumn{2}{|c|}{$\begin{array}{r}2 \cdot 089 \\
* * *\end{array}$}} \\
\hline$P^{\$}$ & \multicolumn{2}{|c|}{ *** } & & & & \\
\hline \multicolumn{7}{|l|}{ Plant height } \\
\hline \multicolumn{7}{|l|}{ TO system } \\
\hline Number of sampled individuals & 35 & 37 & 35 & 80 & - & - \\
\hline Number of observed phenotypes & 4 & 7 & 3 & 11 & - & - \\
\hline Shannon's index & \multicolumn{2}{|c|}{$1 \cdot 105_{* * *}$} & \multicolumn{2}{|c|}{$0.800 * * *$} & - & - \\
\hline
\end{tabular}

${ }^{\$}$ Comparison of Shannon's indices between normal and toxic soils within each site.

*** $P<0 \cdot 001$.

decreases for all the other characters studied (tables 2 and 3 ). There is no site effect (table 5): the three sites studied show similar levels of diversity. Moreover, the response to toxicity is equivalent between sites since the interaction site $x$ toxicity is not significant. The level of significance of the interaction site $\times$ character $(0.098)$ is higher than previously but also not significant.

\section{Genotypic structure}

The $F$ values are calculated for the $G O T-1$ and $A D H$ loci but not for $G O T-2$, for which the level of polymorphism is too low to estimate heterozygote number.

For GOT-1, the pasture populations have high deficits of heterozygotes. The spoil populations

Table 3 Alcohol dehydrogenase locus: number of alleles, allelic frequencies and allelic diversity in normal soil ( $\mathrm{N}$ ) and mine spoil

(T) populations of Arrhenatherum elatius

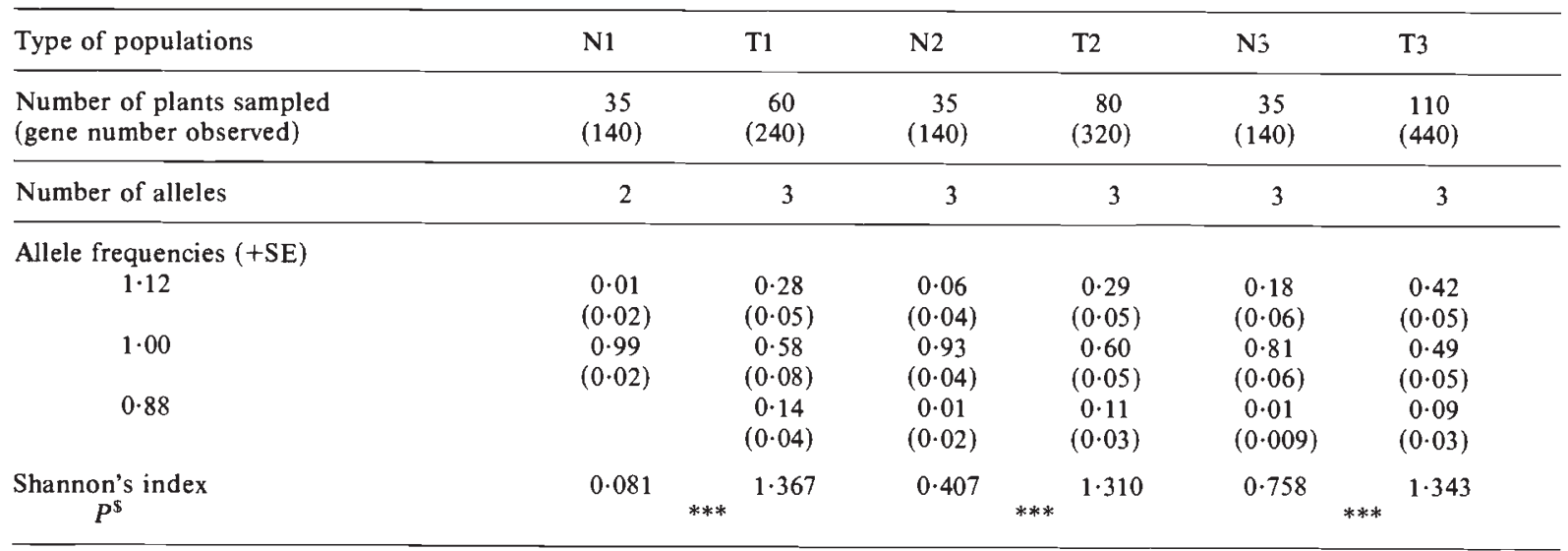

${ }^{\$}$ Comparison of Shannon's indices between normal and toxic soils within each site.

*** $P<0.001$. 
Table 4 Glutamate oxaloacetate transaminase loci ( $G O T-1$ and $G O T-2)$; number of alleles, allelic frequencies and allelic diversity in normal soil (N) and mine spoil ( $\mathrm{T}$ ) populations of Arrhenatherum elatius

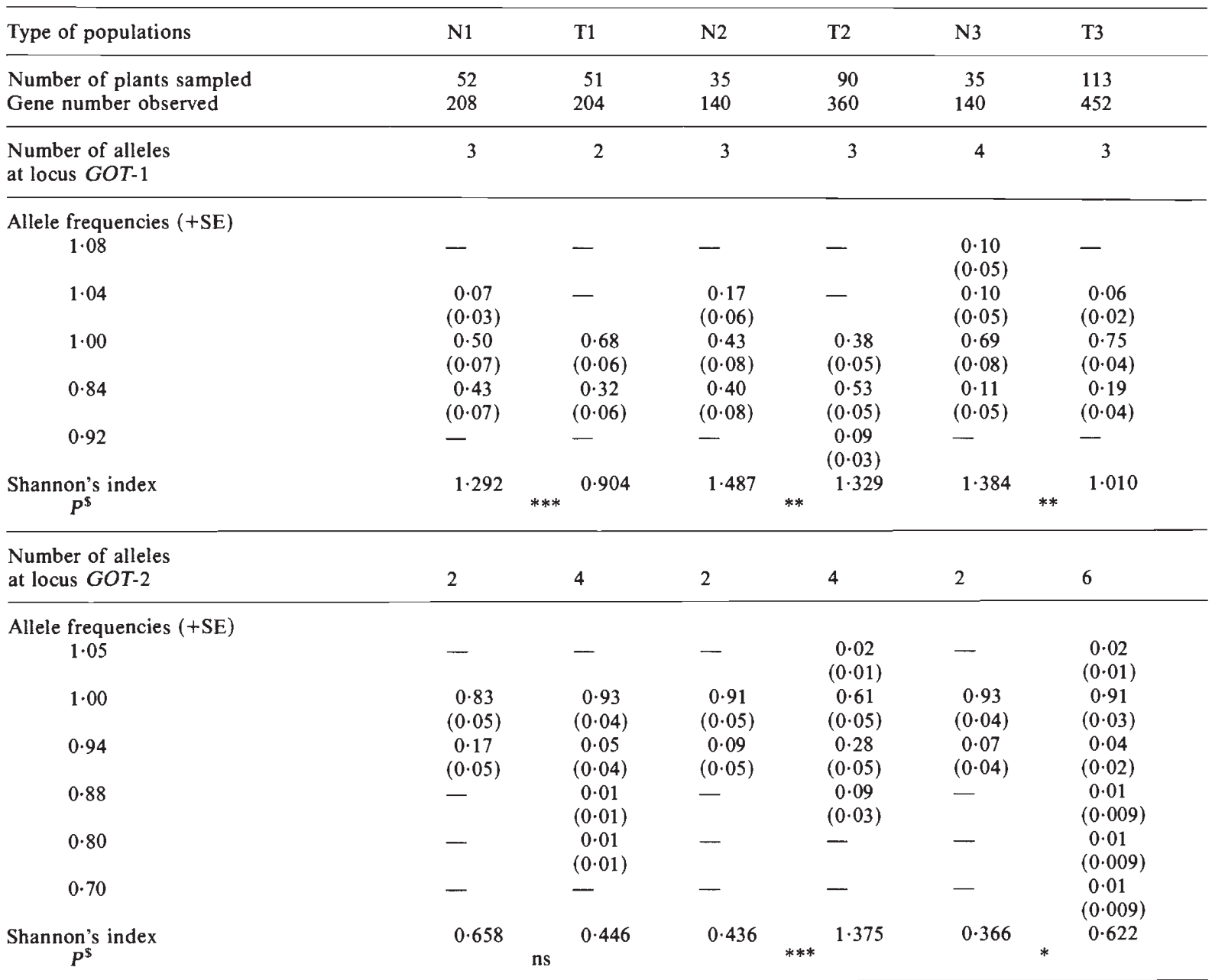

${ }^{\$}$ Comparison of Shannon's indices between normal and toxic soils within in each site.

*** $P<0.001$.

** $P<0.01$.

$* P<0.05$.

ns $=$ not significant.

Table 5 The three-way factorial analysis of variance performed on the Shannon indices

\begin{tabular}{|c|c|c|c|c|c|}
\hline Source of variation & $\begin{array}{l}\text { Sum of } \\
\text { squares }\end{array}$ & $\begin{array}{l}\text { Degree of } \\
\text { freedom }\end{array}$ & Mean square & $F$-ratio & $\begin{array}{l}\text { Significance } \\
\text { level }\end{array}$ \\
\hline \multicolumn{6}{|l|}{ Main effects } \\
\hline Site & 0.045 & 2 & 0.023 & $0 \cdot 18$ & $0 \cdot 840$ \\
\hline Character & $25 \cdot 916$ & 5 & $5 \cdot 183$ & $40 \cdot 88$ & $2 \cdot 10^{-5}$ \\
\hline Toxicity & $3 \cdot 316$ & 1 & $3 \cdot 316$ & $6 \cdot 36$ & 0.053 \\
\hline \multicolumn{6}{|l|}{ Factor interactions } \\
\hline Site-Character & $1 \cdot 268$ & 10 & $0 \cdot 127$ & $2 \cdot 34$ & 0.098 \\
\hline Site-Toxicity & 0.078 & 2 & 0.039 & 0.72 & 0.510 \\
\hline Character-Toxicity & $2 \cdot 609$ & 5 & 0.522 & $9 \cdot 64$ & $1 \cdot 410^{-3}$ \\
\hline Site-Character-Toxicity & 0.541 & 10 & 0.054 & & \\
\hline Total & $33 \cdot 771$ & 35 & & & \\
\hline
\end{tabular}


are very different from one another: a high deficit at site $\mathrm{T} 2$, almost none at site $\mathrm{T} 1$, a slight excess at site $\mathrm{T} 3$. The same pattern of difference appears for locus $A D H$ in spoil populations but $F$ values cannot be taken into account in the pasture populations because of the high frequencies of the 1.00 allele.

In fig. 3, $F$ values are plotted against the number of flowering tillers per square metre. The value of $F$ increases with increasing density. A linear regression analysis of variance confirms that the increase in heterozygote deficit with increase in panicle density is highly significant for GOT-1 $(P<0.001)$. The same trend is obtained with the $A D H$ locus. To verify this result, a complementary study was carried out on site T1. This compared the genetic structure in the centre and peripheral part of a high density area (average density $=100$ panicles per square metre; 152 individuals sampled in the central part and 62 in the peripheral part) with the genetic structure of a low density area (average density $=2$ panicles per square metre; 80 individuals sampled). The same density effect is found for GOT-1 (fig. 3): the central part of the dense zone deviates strongly from panmixia whereas the peripheral part of the dense zone and the low density area are near Hardy-Weinberg equilibrium.

\section{DISCUSSION}

Except for the locus GOT-1, all the characters studied show a higher level of genetic diversity for the mine spoil populations. These results agree with those of $\mathrm{Wu}$ et al. (1975). These authors suggest repeated founder events to explain the increased diversity despite very strong selection. So, a newly evolved tolerant population may have a broad genetic base. This supposes that the tolerant genotype is probably not rare in the normal habitat. If it were, a unique founder event would lead to reduced diversity.

The higher genetic diversity on mine soils might be related either to selective or to neutral effects. On the scale of our study it is not possible to

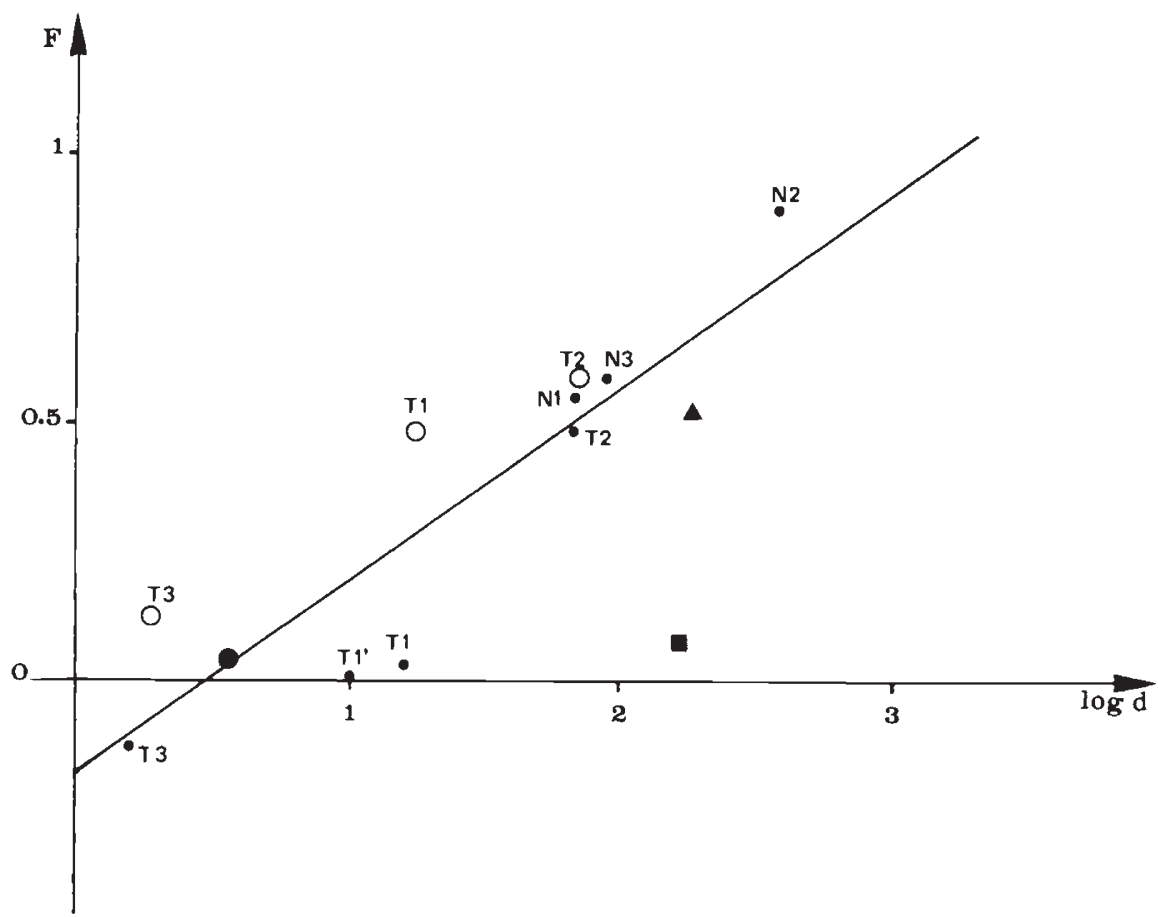

Figure 3 Correlation between $F$ value and density $(d)$. Small points represent data for the locus GOT-1: the regression is given for seven points because Site $\mathrm{T} 1$ has been sampled twice $\left(\mathrm{T} 1, \mathrm{~T} 1^{\prime}\right) . y=0.36 \log d-0 \cdot 16, r=0 \cdot 97, P=0 \cdot 001$. Open circles represent data for the locus $A D H$. Closed triangles represent data for the locus $G O T-1$, from central part of a high density population on toxic ground. Closed squares represent data for the locus GOT-1, from peripheral part of a high density population on toxic ground. Closed circles represent data for the locus GOT-1, from low density population on toxic ground. T (toxic habitat), $\mathrm{N}$ (normal habitat) of sites 1,2 and 3 . 
establish any relation between enzymatic markers and environment (normal or toxic), and the observed variability is probably due to neutral effects. On the other hand, morphological markers result from selective forces. Increased diversity could be the consequence of a spatial heterogeneity (Hedrick et al., 1976) and disturbance by man (Gouyon et al., 1983). Mining habitats can provide a large range of ecological niches. This explanation is well supported by the large variation in amounts of heavy metals from one meter to another on mine soils, contrasting with the homogeneity of pasture soils. The increased diversity in the mine habitat could also result from a low level of competition. Indeed, if on the mine, edaphic selective forces are stronger than on pastures (as indicated by the small number of species on the mine area and the low density of $A$. elatius populations) this may lead to lower selective forces of biotic origin, hence the maintenance of more diversity. In pasture habitats there is a very strong selection competition acting upon various characters such as height, growth and potential for using resources.

Higher diversity might also result from a more open breeding system. Although the mating system and its variation were not studied directly, variations of genetic structure give interesting clues. The high heterozygote deficit in dense populations shown by $F$ values (fig. 3) may be considered as an inbreeding effect perhaps due to more limited gene flow in dense populations, or an increase of actual selfing rate in the high density area. In $A$. elatius the level of self-fertility is relatively low, near 5 per cent according to Pfitzenmeyer (1962) and Sulinowski (1965). In our experiment (Ducousso et al., 1987) the sefing rate is low in pasture populations (on an average 3.02 per cent) while in mine populations a polymorphism for breeding system occurs, some individuals having a high level of self-fertility and other a low level (the average is 11.97 per cent) whatever the density (Cuguen et al., 1989). Therefore, the increased inbreeding in normal populations might be due to the reduction of size of the genetic neighbourhood because of a low dispersal of seed and pollen in a high density area, and not to selfing.

Ellstrand et al. (1978) find that dense populations of Helianthus annuus have lower outcrossing rates than sparse populations, presumably because of intra-family inbreeding in dense population. Such changes in the neighbourhood size has been described in other species, such as Primula vulgaris (Cahalan and Gliddon, 1985). This phenomenon which is very important because it may lead to genetic differentiation, might not be uncommon in many natural populations. Wright (1969) considers that genetic differentiation due to random forces is possible if the neighbourhood size is under 200 and is very strong if it is under 20 . This leads to small subpopulations and a nonrandom distribution. In this case, a Wahlund's effect (1924) appears and reinforces the deficit of heterozygotes.

In consequence, more diversity on toxic area is thus not paradoxical, since: (1) in toxic habitats heterogeneity is higher than in normal habitats and a more diversifying selection occurs at least for characters studied such as panicle height or flowering time; (2) the low dynamism of the colonization of this toxic habitat permits a more open breeding system. With this model of $A$. elatius populations we find again the importance of disturbance as a key factor in the maintenance of genetic diversity which must be taken in account for genetic resource conservation (Soulé and Simberloff, 1986). The multiplication of neighbourhood effects and gene exchanges between sub-populations lead to the maintenance of genetic diversity in the population.

\section{REFERENCES}

ANTONOVICS, J. 1968. Evolution in closely adjacent plant population. V. Evolution of self fertility. Heredity, 23, 219-238.

CAHALAN, C. M. AND GLIDDON, C. 1985. Genetic neighbourhood in Primula vulgaris. Heredity, 54 (1), 65-70.

CUGUEN, J., ACHEROY, M., LOUTFI, A., PETIT, D. AND VERNET, PH. 1989. Breeding system differentiation in Arrhenatherum elatius populations: evolution toward selfing? Evol. Trends in Plants, 3, 17-24.

DuCousso, A. 1985. Comparaison de Populations Adjacentes $d$ 'Arrhenatherum elatius sur des Sols Normaux et Toxiques: Analyse de la Diversité Génétique et du Régime de la Reproduction. Thesis, University of Lille.

DUCOUSSO, A., LOUTFI, A., PETIT, D., ACHEROY, M., VALERO, M. AND VERNET, PH. 1987. Structure génétique et régime de la reproduction chez Arrhenatherum elatius L., Coll. Nat. CNRS "Biologie des Populations", Lyon, 4-7 Sept. 1986, pp. 317-319.

Ellstrand, N. C., TORRES, A. M. AND LEVIN, D. A. 1978. Density and the rate of apparent outcrossing in Helianthus annuus (Asteraceae). Syst. Bot, 3, 403-407.

GARTSIDE, D. W. AND MCNEILLY, T. 1974. The potential for evolution of heavy metal tolerance in plants. II. Copper tolerance in normal populations of different plant species. Heredity, 3, 335-348

GOUYON, P. H., LUMARET, R., VALDEYRON, G. AND VERNET, PH. 1983. Reproductive strategies and disturbance by Man, in Mooney, H. A. and Godron, M. (eds) Disturbance and Ecosystems. Component of response. Ecological Studies 44, Springer-Verlag, pp. 214-225.

HEDRICK, P. W., GINEVAN, M. E. AND EWING, E. P. 1976. Genetic polymorphism in heterogeneous environments. Ann. Rev. Ecol. Syst., 7, 1-32. 
HUTCHESON, K. 1970. A test for comparing diversities based on the Shannon formula. J. theor. Biol, 29, 151-154.

LEFEBVRE, C. 1970. Self-fertility in maritime and zinc mine populations of Armeria maritima (Mill.) Willd. Evolution, $24,571-577$.

LEFEBVRE, C. AND KAKES, P. 1978. Variation electrophorétique cles estérases des feuilles d'Armeria maritima (Mill.) Willd: çuelques aspects taxonomiques et évolutifs. Bull. Soc. Roy. Bot. Belg., 114, 31-40.

LOUTFI, A. 1987. Variabilité du Régime de la Reproduction au Sein des Populations d'Arrhenatherum elatius de Milieux Contrastés. Thesis, University of Lille.

LUMARET, R. 1981. Structure génétique d'un complexe poly. ploïde Dactylis glomerata L.. Thesis, U.S.T.L. Montpellier, $168 \mathrm{p}$.

McNEILly, T. AND ANTONOviCS, J. 1968. Evolution in closely adjacent plant populations. IV. Barriers to gene flow. Heredity, 40, 371-384.

PFITZENMEYER, C. D. 1962. Biological flora of the British Isles: Arrhenatherum Elatius (L.) J. et C. Presl.. J. Ecol., 50, 235-245.

SHANNON, C. E. AND WEAVER, w. 1963. The Mathematical Theory of Communication. Urbana Univ. Illinois Press.

SOKAL, R. R. AND ROHLF, F. J. 1981. Biometry: The Principles and Practice of Statistics in Biological Research. Second edn. W. H. Freeman, New York, USA.
SOULE, M. E. AND SIMBERLOFF, D. 1986. What do genetics and ecology tell us about design of nature reserves? Biolog. Cons., 35, 19-40.

SULINOWSKI, S. 1965. Variation of forms and biology of flowering in Arrhenatherum elatius (L.) P.B. Part II. Effects of self and cross pollination on seed setting in Arrhenatherum elatius. Genetica Polonica, 6, 105-118.

VERKLEIJ, J. A. C., BAST-CRAMER, W. B. AND LEVERING, H 1985. Effect of heavy metal stress on the genetic structure of populations of Silene cucubalus. In Haeck, J. and Woldendorp, J. W. (eds) Structure and Fonctionning of Plant Populations, vol. 2, North-Holland Publishing Company, Amsterdam, pp. 355-365.

WAHLUND, S. 1928. Zuzammenzung von populationen und korelationscheinungen vom standpunkt der vererbungslehere aus betrachtet. Hereditas 11, 65-106.

WRIGHT, S. 1969. Theory of Gene Frequencies. University of Chicago Press, Chicago, vol. 2.

WU, L., BRADSHAW, A. D. AND THURMAN, D. A. 1975. The potential for evolution of heavy metal tolerance in plants. III. The rapid evolution of copper tolerance in Agrostis stolonifera. Heredity, 34, 165-185. 